\title{
PRE-CAMBRIAN DIAMOND-BEARING VEINED BODIES FROM SOUTH-WEST OF THE SIBERIAN PLATFORM.
}

A.P. Sekerin; Yu. V. Menshagin; B.M. Vladimirov and V.A. Lashchenov.

Institute of the Earth's Crust, 664033 - Irkutsk, USSR.

The structural position and mineral composition of diamondbearing veins which have previously been classified as mica kimberlites from South-West of the Siberian Platform are discussed.

The veined bodies are localizated within the limits of the Early Proterozoic intracratonnal mobile zone cratonized at the Upper Riphean-Vend. Picrites, basalts, trachybasalts, ultrapotassic trachytes, alkaline-ultrabasic rocks and carbonatites, and ultrapotassic basaltic picrites were intruded. The late two rock types contain some high-pressure minerals.

The diamond-bearing bodies occur as veins, which lengh is up to $1 \mathrm{~km}$ and the thickness varies from some $\mathrm{cm}$ up to $1 \mathrm{~m}$. The country rock matrix is texturally porphyric and structurally fluidal. Porphyric phenocrysts are represented by serpentine and talc psedomorphs after olivine and by phlogopite. The oriented microlites of phlogopite enclosed in the apoglassy matrix predominate in the ground mass. Carbonate is found as a rock-forming mineral in one vein in which limestone interbeded the country rocks. The available data coupled with isotopic studies allow the secondary assimilation origin of carbonate to be assumed.

Inclusions of ultrabasic rocks and eclogitizated gabbro are observed in veins.

The studied rocks are petrochemically different from kimberlites and they are similar to olivine lamproites from the Argyle pipe. They also differ from kimberlites in concentrations and ratios of coherent and non-coherent elements and correspond to lamproites from West Australia. 
The rocks are dated by $\mathrm{Rb}-\mathrm{Sr}$ age determination of $1268 \pm 12 \mathrm{~m} \cdot \mathrm{y}$. Age of the alkaline-ultrabasic rocks of carbonatitic complex from the same region is $640-740 \mathrm{~m} . \mathrm{y}$.

A characteristic mineralogical feature is the predomonence of chrome-spinellids in ore minerals and the orange almandinepyropes of eclogitic paragenesis in garnets (Pyr=38\%, Alm $=34 \%$, Gross=24\%). Picroilmenites and low manganous ilmenites are absent. Ilmenites are characterised by a higher (up to $4 \%$ ) $\mathrm{Mg}$ content. Three amphibole types are distinguished: potassic magnesioarfvedsonite, titanopargasite and unidentified chrome-bearing ultrapotassic amphibole. The higher $\mathrm{TiO}_{2}$ content is common to phlogopite $(f=10-25 \%)$. The mineral compositions, of olivine, orthopyroxene, chrome-diopside and chrome-spinellids are studied. Zircons, Nb-rutile, anatase, moissanite, spinel, apatite, sphene, turmaline, epidote, armalcolite, priderite and diamonds occur in these rocks.

The analysis of the available data suggests a lamproitic origin of rocks studied. 